\title{
DUKUNGAN SOSIAL DAN TINGKAT STRES ORANG DENGAN HIV/AIDS
}

\author{
Yona Kurnia Sari, Ice Yulia Wardani* \\ Fakultas Ilmu Keperawatan Universitas Indonesia, Depok 16424, Indonesia \\ *E-mail: iceyulia@ui.ac.id
}

\begin{abstract}
Abstrak
Kondisi HIV/AIDS menimbulkan stres bagi para penederitanya. Salah satu cara untuk mengurangi stres adalah mencari dukungan sosial. Tujuan penelitian ini adalah untuk mengidentifikasi hubungan antara dukungan sosial dengan tingkat stres orang dengan HIV/AIDS di Kota Depok. Desain penelitian yang digunakan adalah deskriptif korelasi dengan pendekatan cross sectional terhadap 77 orang dengan HIV/AIDS dengan menggunakan metode pengampilan sampel consequtive sampling. Instrumen yang digunakan yaitu Medical Outcomes Sosial Support Survey HIVdan Perceives Stress Scale HIV. Hasil penelitian ini mendapatkan bahwa dukungan sosial yang diterima responden tergolong tinggi $(55,8 \%)$ dan tingkat stres responden berada dalam kategori stres berat $(80,5 \%)$. Hasil analisis bivariat menemukan bahwa ada hubungan antara dukungan sosial dengan tingkat stres $(\mathrm{p}<0,05)$. Hasil penelitian ini merekomendasikan dukungan sosial sebagai salah satu cara untuk membantu orang dengan HIV/AIDS menurunkan tingkat stresnya, dengan memberikan prioritas yang lebih pada dukungan materi.
\end{abstract}

Kata Kunci: Dukungan sosial, HIV/AIDS, tingkat stres

\begin{abstract}
Social Support and Stress among People Living with HIV/AIDS. The impact of HIV/AIDS causes stress to people living with HIV/AIDS (PLWHA). Seeking a social support is one method to reduce stress for people living with PLWHA. The purpose of this study was to determine the relationship between social support and stress levels of people with HIV/AIDS in Depok city. The study design was a descriptive correlation with the cross-sectional study of 77 people with HIV/AIDS by using a consecutive sampling. Instruments used namely Medical Outcomes Survey of Social Support HIV (HIV-MOSS) and Perceive HIV Stress Scale (PSS-HIV). The results of this study found that the social support received by respondents is high (55.8\%) and stress levels of respondents mostly were in severe stress (80.5\%). The results of the bivariate analysis found that there is a relationship between social support and stress levels $(p<0.05)$. The results of this study recommend social support as a way to help people with HIV/AIDS reduces the stress level, by giving higher priority to the material support.
\end{abstract}

Keywords: HIV/AIDS, social support, stress level

\section{Pendahuluan}

HIV/AIDS menimbulkan banyak dampak pada orang dengan HIV/AIDS (ODHA). Apabila dampak tersebut tidak dapat diatasi maka akan menyebabkan timbulnya masalah-masalah baru. Masalah yang dialami oleh penderita HIV/AIDS terbagi kedalam masalah fisik, emosional dan psikososial (Vreeman, Scanlon, McHenry, \& Nyandiko, 2015). Masalah fisik dapat terjadi dari akibat proses penyakit dan proses perawatan dari penyakit itu sendiri. Sedangkan masalah emosional dapat terjadi karena pengaruh obat-obatan yang dikonsumsi. Masalah psikososial pada penderita HIV/AIDS juga sering terjadi, salah satunya karena stigma dari masyarakat mengenai HIV/AIDS (Waluyo, Nurachmah, \& Rosakawati, 2014). Penelitian sebelumnya oleh Kose, Mandiracioglu, Mermut, Kaptan, dan Ozbel (2012) di Turki yang menemukan bahwa penderita HIV/AIDS menyatakan bahwa mereka mempunyai beberapa masalah yang berhubungan dengan kesehatan, moral, sosial dan keuangan. Diskriminasi di- 
tempat kerja juga merupakan masalah yang besar. Kesempatan untuk bekerja semakin sedikit dan pendapatan berkurang, akan tetapi masalah yang berhubungan dengan penanganan HIV/AIDS ini semakin tinggi. Hal-hal ini membuat tingkat stres penderita HIV/AIDS meningkat. Stres merupakan suatu keadaan ketika individu merespon perubahan dalam status keseimbangan normal (Berman, Snyder, \& Frandsen, 2015).

Salah satu manajemen untuk mengatasi stres yaitu dengan mencari dukungan sosial. Penelitian yang dilakukan Casale dan Wild (2013) menemukan bahwa dukungan sosial dapat memberikan efek positif terhadap kesehatan mental pada penderita HIV/AIDS. Efek positif tersebut yaitu dengan meningkatkan kemungkinan strategi yang aktif dalam menghadapi stres seperti mencari dukungan dan mampu berhadapan dengan stressor, dan menurunkan kemungkinan melakukan strategi yang pasif seperti menghindar dan emosional. Lyons dan Gillis (2010) juga menemukan bahwa kebutuhan akan dukungan sosial sangat membantu untuk menguatkan penderita HIV/AIDS sehingga dapat menurunkan tingkat depresinya. Dukungan sosial merupakan kenyamanan, kepedulian, penghormatan, atau membantu seseorang untuk benar-benar menerima atau hanya merasakan bahwa hal-hal tersebut dapat diperoleh dari orang lain (Sarafino \& Smith, 2012).

Jumlah orang yang terinfeksi HIV semakin lama semakin banyak. Semakin banyaknya ODHA, maka akan meningkatkan kebutuhan pengetahuan mengenai cara yang terbaik untuk membantu meringankan beban ODHA tersebut. Oleh karena itu, peneliti tertarik untuk mengangkat hal ini. Selain itu, di wilayah Kota Depok belum pernah dilakukan penelitian yang membuktikan keterkaitan antara dukungan sosial dengan tingkat stres ODHA. Oleh karena itu, perlu dilakukan penelitian untuk mengetahui hubungan dukungan sosial dengan tingkat stres penderita HIV/AIDS di wilayah Kota Depok.

\section{Metode}

Penelitian ini menggunakan desain penelitian deskriptif korelatif terhadap 77 orang penderita HIV/AIDS di sebuah Lembaga Swadaya Masyarakat (LSM) yang membidangi pendampingan ODHA di Kota Depok. Tujuannya yaitu untuk melihat hubungan antara dukungan sosial dengan tingkat stres penderita HIV/AIDS dengan pendekatan cross sectional dan dianalisis dengan analisis univariat dan bivariat.

Instrumen penelitian ini berupa kuesioner yang terdiri dari tiga bagian. Bagian pertama yaitu karakteristik responden (usia, jenis kelamin, pendidikan, pekerjaan, dan suku). Bagian kedua yaitu Medical Outcomes Social Support Survey HIV (MOSS-HIV). Bagian ketiga yaitu Perceived Stress Scale HIV (PSS-HIV). Instrumen penelitian ini telah dilakukan uji validitas dan reliabilitas kembali oleh peneliti. MOSSHIV memiliki nilai Cronbach $\alpha$ 0,915 dan PSSHIV memiliki nilai Cronbach $\alpha 0,754$. Berdasarkan hal tersebut dapat dinyatakan bahwa kedua instrumen yang digunakan sudah terbukti valid dan reliabel.

Prosedur penelitian pertama yaitu mengajukan permohonan pengantar izin penelitian kepada Dekan FIK Universitas Indonesia. Setelah itu peneliti mengajukan izin penelitian ke LSM tersebut. Peneliti melakukan pengambilan data dengan dibantu anggota LSM untuk menghubungi dan meminta persetujuan penderita HIV/ AIDS untuk mengisi kuesioner dengan menjelaskan tujuan penelitian dan cara pengisian kuesioner ini. Pengambilan data ini dilakukan selama dua bulan.

\section{Hasil}

Rentang usia responden 24-39 tahun dengan rerata 31,7 tahun dan standar deviasi 3,937. Responden rerata telah didiagnosis HIV selama 52,52 bulan dengan standar deviasi 40,543. Mayoritas responden adalah laki-laki $(59,7 \%)$. Pendidikan responden pada penelitian ini mayoritas SMA 54,5\%. Ibu rumah tangga (IRT) 
$28,6 \%$ merupakan mayoritas dan disusul oleh pekerjaan lainya yang tidak disebutkan dalam penelitian ini $22,1 \%$, setelah itu wiraswasta $18,2 \%$, PNS dan tidak bekerja masing-masing $11,7 \%$ dan terakhir karyawan 7,8\%. Responden terbanyak berasal dari suku Betawi 29,9\% dan disusul suku Sunda 23,4\%, Jawa 22,1\%, Minang 6,5\%, Batak 5,2\%, dan dari suku lainnya di Indonesia $13 \%$.

Hasil penelitian ini juga mendapatkan bahwa $55,8 \%$ responden mendapatkan dukungan sosial sudah baik dan mayoritas responden memiliki stres berat. Distribusi dukungan sosial jika dilihat dari bentuknya dapat dilihat pada tabel 1 dan hasil tentang tingkat stres dapat dilihat pada tabel 2 .

Pada Tabel 3 hasil uji statistik didapatkan nilai $\mathrm{p}$ sebesar $0,000(\mathrm{p}<0,001)$. Berarti terdapat hubungan yang signifikan antar dukungan sosial dengan tingkat stres. Pada Tabel 4 hasil uji statistik didapatkan nilai $\mathrm{p}$ sebesar 0,066 (p> 0,05). Hal ini berarti tidak terdapat hubungan yang signifikan antar dukungan emosi dengan tingkat stres.

Tabel 1. Distribusi Dukungan Sosial berdasarkan Bentuk Dukungan

\begin{tabular}{lcccc}
\hline & \multirow{2}{*}{ Bentuk Dukungan } & \multicolumn{2}{c}{ Frekuensi (n) } & \multicolumn{2}{c}{ Persentase (\%) } \\
\cline { 2 - 5 } & Tinggi & Rendah & Tinggi & Rendah \\
\hline Emosi & 35 & 42 & 45,5 & 54,5 \\
Materi & 44 & 33 & 57,1 & 42,9 \\
Informasi & 55 & 22 & 71,4 & 28,6 \\
Persahabatan & 46 & 31 & 59,7 & 40,3 \\
\hline
\end{tabular}

Tabel 2. Distribusi Tingkat Stres

\begin{tabular}{lccc}
\hline & Stres & Frekuensi (n) & Persentase (\%) \\
\hline Ringan & & 15 & 19,48 \\
Berat & 62 & 80,52 \\
\hline
\end{tabular}

Tabel 3. Hubungan Dukungan Sosial dengan Tingkat Stres

\begin{tabular}{|c|c|c|c|c|c|c|c|}
\hline \multirow{3}{*}{$\begin{array}{c}\text { Dukungan } \\
\text { Sosial }\end{array}$} & \multicolumn{4}{|c|}{ Tingkat Stres } & \multirow{3}{*}{ Total } & \multirow{3}{*}{$\mathrm{p}$} & \multirow{3}{*}{$\begin{array}{c}O R \\
(95 \% \mathrm{CI})\end{array}$} \\
\hline & \multicolumn{2}{|c|}{ Ringan } & \multicolumn{2}{|c|}{ Berat } & & & \\
\hline & Jumlah & $\%$ & Jumlah & $\%$ & & & \\
\hline Rendah & 2 & 4,7 & 41 & 95,3 & 43 & 0.0000 & 0,079 \\
\hline Tinggi & 13 & 38,2 & 21 & 61,8 & 34 & & $(0,16-0,382)$ \\
\hline Total & 15 & 19,5 & 62 & 80,5 & 77 & & \\
\hline
\end{tabular}

Tabel 4. Hubungan Dukungan Emosi dengan Tingkat Stres

\begin{tabular}{|c|c|c|c|c|c|c|c|}
\hline \multirow{3}{*}{ Dukungan Emosi } & \multicolumn{4}{|c|}{ Tingkat Stres } & \multirow{3}{*}{ Total } & \multirow{3}{*}{$\mathrm{p}$} & \multirow{3}{*}{$\begin{array}{c}\text { OR } \\
(95 \% \mathrm{CI})\end{array}$} \\
\hline & \multicolumn{2}{|c|}{ Ringan } & \multicolumn{2}{|c|}{ Berat } & & & \\
\hline & Jumlah & $\%$ & Jumlah & $\%$ & & & \\
\hline Rendah & 5 & 11,9 & 37 & 88,1 & 42 & 0066 & 0,038 \\
\hline Tinggi & 10 & 28,6 & 25 & 71,4 & 25 & 0.066 & $(0,103-1,108)$ \\
\hline Total & 15 & 19,5 & 62 & 80,5 & 77 & & \\
\hline
\end{tabular}


Tabel 5. Hubungan Dukungan Materi dengan Tingkat Stres

\begin{tabular}{|c|c|c|c|c|c|c|c|}
\hline \multirow{3}{*}{ Dukungan Materi } & \multicolumn{4}{|c|}{ Tingkat Stres } & \multirow{3}{*}{ Total } & \multirow{3}{*}{$\mathrm{p}$} & \multirow{3}{*}{$\begin{array}{c}\text { OR } \\
(95 \% \mathrm{CI})\end{array}$} \\
\hline & \multicolumn{2}{|c|}{ Ringan } & \multicolumn{2}{|c|}{ Berat } & & & \\
\hline & Jumlah & $\%$ & Jumlah & $\%$ & & & \\
\hline Rendah & 2 & 6,1 & 31 & 93,9 & 33 & 0010 & 0,154 \\
\hline Tinggi & 13 & 29,55 & 31 & 70,45 & 44 & 0.010 & $(0,032-0,739)$ \\
\hline Total & 15 & 19,48 & 62 & 80,5 & 77 & & \\
\hline
\end{tabular}

Tabel 6. Hubungan Dukungan Informasi dengan Tingkat Stres

\begin{tabular}{|c|c|c|c|c|c|c|c|}
\hline \multirow{3}{*}{ Dukungan Informasi } & \multicolumn{4}{|c|}{ Tingkat Stres } & \multirow{3}{*}{ Total } & \multirow{3}{*}{$\mathrm{p}$} & \multirow{3}{*}{$\begin{array}{c}\text { OR } \\
(95 \% \mathrm{CI})\end{array}$} \\
\hline & \multicolumn{2}{|c|}{ Ringan } & \multicolumn{2}{|c|}{ Berat } & & & \\
\hline & Jumlah & $\%$ & Jumlah & $\%$ & & & \\
\hline Rendah & 5 & 22,7 & 17 & 77,3 & 22 & 0640 & 1,324 \\
\hline Tinggi & 10 & 18,2 & 45 & 81,8 & 55 & 0.649 & $(0,395-4,438)$ \\
\hline Total & 15 & 19,5 & 62 & 80,5 & 77 & & \\
\hline
\end{tabular}

Tabel 7. Hubungan Dukungan Persahabatan dengan Tingkat Stres

\begin{tabular}{|c|c|c|c|c|c|c|c|}
\hline \multirow{3}{*}{ Dukungan Persahabatan } & \multicolumn{4}{|c|}{ Tingkat Stres } & \multirow{3}{*}{ Total } & \multirow{3}{*}{$\mathrm{p}$} & \multirow{3}{*}{$\begin{array}{c}\text { OR } \\
(95 \% \mathrm{CI})\end{array}$} \\
\hline & \multicolumn{2}{|c|}{ Ringan } & \multicolumn{2}{|c|}{ Berat } & & & \\
\hline & Jumlah & $\%$ & Jumlah & $\%$ & & & \\
\hline Rendah & 5 & 16,1 & 26 & 83,9 & 31 & 0 770 & 0,692 \\
\hline Tinggi & 10 & 21,7 & 36 & 78,3 & 46 & 0.170 & $(0,211-2,267)$ \\
\hline Total & 15 & 19,5 & 62 & 80,5 & 77 & & \\
\hline
\end{tabular}

Pada Tabel 5 hasil uji statistik didapatkan nilai $\mathrm{p}$ sebesar 0,010 ( $\mathrm{p}<0,05)$. Berarti terdapat hubungan yang signifikan antara dukungan materi dengan tingkat stres.

Hasil uji statistik pada Tabel 6 didapatkan nilai p sebesar 0,649 ( $p>0,05)$. Berarti, tidak terdapat hubungan yang signifikan antar dukungan informasi dengan tingkat stres.

Hasil uji statistik pada Tabel 7 didapatkan nilai p sebesar 0,770 (p>0,05). Berarti, tidak terdapat hubungan yang signifikan antar dukungan persahabatan dengan tingkat stres.

\section{Pembahasan}

Hasil penelitian ini menunjukkan bahwa lakilaki lebih banyak daripada perempuan. Sejalan dengan data yang dikemukan oleh Kementerian Kesehatan RI (2014) yang juga menyebutkan bahwa penderita HIV/AIDS di Indonesia lebih banyak laki-laki dari pada perempuan. Hal ini dimungkinkan karena laki-laki lebih banyak melakukan perilaku berisiko sehingga rentan terinfeksi.

Rerata usia responden yaitu 31,7 tahun. Hal ini sejalan dengan penelitian yang dilakukan oleh Kusuma (2011) pada pasien HIV/AIDS di RSCM yang menemukan rerata usia responden yaitu 30,43 tahun. Kelompok usia ini juga termasuk kelompok usia produktif. Hal ini menunjukkan bahwa kelompok usia produktif memiliki peran yang besar menularkan HIV/AIDS maupun risiko tinggi dalam tertular HIV karena pada kelompok ini, aktivitas seksual cukup tinggi. Hal ini sesuai dengan penelitian Freeman dan Anglewicz (2012) yang melaporkan bahwa 15-49 tahun merupakan usia dengan prevalensi HIV tertinggi.

Pendidikan responden telah cukup baik. Hal ini sejalan dengan penelitian yang dilakukan 
oleh Natalya (2006) menemukan bahwa responden yang berpendidikan lebih tinggi lebih terbuka. Selain itu, responden yang pendidikannya lebih tinggi lebih banyak yang memilih melakukan kegiatan atau mengikuti kegiatan di pelayanan ODHA untuk mencegah terjadinya kasus baru.

Mayoritas responden merupakan ibu rumah tangga (IRT). Hal ini disebabkan karena 4,9 juta perempuan menikah dengan laki-laki yang sering melakukan perilaku berisiko, dan sebanyak 6,7 juta laki-laki merupakan pelanggan seks bebas (BBC, 2015). Berdasarkan hal tersebut dapat dikatakan bahwa IRT yang menderita HIVAIDS umumnya tertular dari suami mereka.

Mayoritas responden berasal dari suku Betawi, Sunda, dan Jawa. Hal ini dipengaruhi oleh tempat dilakukannya penelitian yang umumnya masyarakat berasal dari Betawi, Sunda, dan Jawa. Hal ini juga didukung oleh penelitian yang dilakukan oleh Rachmanissa (2013) yang juga menemukan bahwa mayoritas respondennya mempunyai suku tergantung kepada tempat penelitiannya.

Berdasarkan hasil penelitian ini didapatkan secara umum dukungan sosial responden termasuk tinggi. Hal ini dapat terjadi karena pengambilan data penelitian ini dilakukan di sebuah LSM. Hal ini hampir sama dengan penelitian yang dilakukan oleh Widyanti (2008) yang mendapatkan bahwa dukungan sosial yang dirasakan oleh penderita HIV/AIDS tergolong tinggi.

Berdasarkan bentuk dukungan sosialnya, dukungan emosi masih kurang. Hal ini mungkin terjadi karena dukungan yang diterima oleh responden tidak sesuai dengan yang dibutuhkannya, atau tidak cukup dan kemungkinan lainnya bisa karena responden tersebut merasa tidak perlu mendapatkan bantuan sehingga dukungan yang diberikan tidak diperhatikan (Sarafino \& Smith, 2012). Kemungkinan lainnya juga dapat dikarenakan penderita HIV/
AIDS tersebut belum mendapatkan dukungan emosional yang cukup sehingga mereka tetap aktif di kelompok dukungan. Hal ini sejalan dengan penelitian yang dilakukan AbrefaGyan, Wu, dan Lewis (2015) yang menemukan bahwa semakin sering dan banyak seseorang menerima dukungan emosi maka kehadiran di kelompok dukungan akan semakin berkurang. Oleh karena itu, responden penelitian ini masih sering mengikuti kelompok dukungan untuk mendapat dukungan emosi yang lebih lagi.

Dukungan materi responden telah banyak yang menyatakan baik. Kemungkinan karena LSM tersebut membantu ODHA untuk mendapatkan ARV lebih mudah. Selain itu, LSM juga sering melakukan kegiatan-kegiatan bakti sosial sehingga ODHA mendapatkan bantuan secara langsung. Penelitian yang dilakukan AbrefaGyan, et al. (2015) di Ghana menemukan bahwa semakin banyak dukungan materi yang diberikan maka semakin lama seseorang bertahan di dalam kelompok dukungan sosial.

Responden banyak yang menyatakan bahwa dukungan informasinya sudah baik. Hal ini juga dikarenakan responden yang diambil dalam penelitian ini tergabung kedalam sebuah LSM. LSM yang memang tujuannya untuk mendukung para ODHA dengan memberikan informasi, baik tentang penyakit maupun pengalaman yang telah dilalui oleh ODHA lama sehingga dapat menjadi pelajaran untuk ODHA lainnya.

Dukungan persahabatan responden lebih banyak tergolong tinggi. Seperti yang dijelaskan sebelumnya hal ini dikarenakan mereka telah tergabung ke dalam suatu LSM. Pada LSM tersebut ODHA mendapatkan sarana untuk berbagai dengan orang-orang yang senasib dengan mereka.

Tingkat stres responden yang didapatkan dari penelitian ini lebih banyak yang tergolong stres berat. Hal ini menunjukkan bahwa masih tingginya tingkat stres yang dialami oleh 
ODHA pada responden penelitian ini, walaupun mereka telah tergabung ke dalam kelompok dukungan. Banyak yang menyebabkan hal ini, salah satunya yaitu cara memandang suatu masalah sehingga masalah tersebut dapat dikatakan sebagai sumber stres atau tidak. Selain itu, masalah yang ditimbulkan oleh HIV/AIDS ini dapat terjadi pada berbagai hal. Ketidakmampuan ODHA untuk menangani seluruh masalah tersebut juga menyebabkan stres yang tinggi. Hasil ini didukung oleh penelitian yang dilakukan Natalya (2006) di Yogyakarta menemukan bahwa penderita HIV/ AIDS mengalami stres berat dalam menghadapi penyakitnya.

Penelitian yang dilakukan oleh Kaijage dan Wexler (2010) menemukan bahwa ODHA akan lebih stres dari pada orang lainnya tetapi dengan dukungan sosial yang didapatkannya dapat mengurangi stres tersebut. Hasil penelitian ini mendukung hasil penelitian tersebut. Penelitian ini mendapatkan hasil bahwa terdapat hubungan yang kuat antara dukungan sosial dengan tingkat stres $(\mathrm{p}<0,005)$. Hal ini dapat terjadi karena berbagai hal. Pertama, responden penelitian ini merupakan anggota di sebuah LSM yang memberikan dukungan terhadap ODHA. Kedua, responden rata-rata terdapat pada kelompok usia dewasa muda. Pada saat dewasa muda, seseorang akan menjalani beberapa perubahan dikehidupannya dari remaja menuju dewasa dengan banyaknya tuntutan. Ketiga, karena responden pada penelitian ini umumnya sudah menyatakan bahwa mereka menerima dukungan sosial yang tinggi.

Dilihat dari bentuk dukungan sosialnya, pada uji statistik dukungan emosi menunjukan tidak ada hubungan yang signifikan dengan tingkat stres. Dukungan emosi yang dibutuhkan oleh ODHA yaitu dari orang tua, anggota keluarga, lingkungan sosial lainya seperti kekasih dan teman kerja. Akan tetapi, masih banyaknya ODHA yang belum membuka status HIV positifnya kepada orang-orang tersebut sehingga mereka akan kesulitan dalam mencari du- kungan emosi. Hal ini juga dapat disebabkan oleh keberadaan dukungan emosional tersebut tidak selalu ada dan mudah untuk dijangkau.

Sejalan dengan Agustanti (2006) yang menemukan bahwa keberadaan keluarga yang paling dekat dengan ODHA dibandingkan teman, tenaga profesional, maupun profesional. Akan tetapi tidak semua ODHA menjadikan keluarga sebagai sumber dukungan. Oleh karena itu, ketika ODHA membutuhkan dukungan emosi, keberadaan sumber dukungan tersebut tidak selalu ada sehingga ODHA merasa kurang puas. Walaupun responden berada dalam pendampingan LSM, akan tetapi dukungan emosi yang dibutuhkan oleh responden belum tentu dapat terpenuhi seutuhnya oleh LSM tersebut. Hal ini dikarenakan oleh banyaknya anggota kelompok dukungan tersebut, dukungan emosi yang diberikan tidak sesuai dengan yang dibutuhkan baik dari segi waktu maupun dukungan yang diberikan, dan bisa juga diakibatkan karena responden itu sendiri yang lebih bersifat tertutup dan tidak mampu menerima dukungan emosional yang telah diberikan orang lain.

Berdasarkan dukungan materi, penelitian ini juga menemukan hubungan yang kuat antara dukungan materi dengan tingkat stres pada penderita HIV/AIDS. Banyak faktor memengaruhi hal ini. Pertama, jumlah terbanyak yaitu IRT. IRT mempunyai sumber keuangan yang hanya berasal dari suaminya saja. Adanya dukungan materi yang diberikan, maka akan sangat membantu mereka meringankan beban ekonomi. Selain itu, mayoritas responden sudah tergolong lama terdiagnosis. Semakin lama seseorang terinfeksi HIV maka akan semakin banyak masalah yang timbul, contohnya masalah karena penyakit penyerta. Hal tersebut dapat menyebabkan biaya yang dibutuhkan akan semakin tinggi.

Rerata responden merupakan kelompok usia dewasa muda. Pada dewasa muda seseorang mulai memiliki banyak tanggung jawab seperti tangung jawab terhadap kondisi keluarganya. 
Sehingga membutuhkan dukungan materi ini. Hal ini didukung oleh penelitian yang dilakukan oleh Tang (2001) yang meneliti terhadap 410 orang yang menderita HIV/AIDS juga menemukan hubungan yang kuat antara dukungan materi dengan tingkat stres. Earnshaw, Lang, Lippitt, Jin, dan Chaudoir (2015) menemukan dukungan sosial berupa instrumen, dukungan yang didapat dari komunitas, dan social support, perceived community support, dan sentralitas identitas HIV yang menyangga peserta berhubungan dengan stigma yang diantisipasi dan gejala HIV.

Pada dukungan informasi, menunjukan bahwa tidak ada hubungan antara dukungan informasi dengan tingkat stres yang dialami oleh penderita HIV/AIDS. Hal ini karena dukungan informasi yang diterima oleh ODHA pada penelitian ini tidak sesuai dengan yang dibutuhkannya, atau juga karena dukungan informasi yang diterima membingungkan atau juga dapat karena informasi yang diterima kurang dapat dipahami oleh ODHA itu sendiri. Hal ini didukung oleh pernyataan Campbel, Mamame, Nair, dan Sybia (2005) yang mengatakan bahwa kurangnya informasi, atau informasi yang salah, atau informasi yang membingungkan dapat membawa respon negatif bagi ODHA. Hal ini diperkuat oleh laporan dari Khamarko dan Myers (2013) yang menyebutkan bahwa dukungan sosial, termasuk dukungan informasi akan memberikan dampak yang baik bagi ODHA dan keluarganya.

Berdasarkan dukungan persahabatan, penelitian ini mendapatkan bahwa tidak ada hubungan yang signifikan antara dukungan persahabatan dengan tingkat stres penderita HIV/AIDS. Hasil ini tentu tidak sejalan dengan studi sebelumnya yang melaporkan adanya hubungan antara dukungan sosial, berupa pertemanan dengan tingkat stres ODHA (Casale \& Wild, 2013; Earnshaw, et al., 2015; Khamarko \& Myers, 2013). Hasil ini dapat terjadi karena berbagai sebab, termasuk karena tingkat stres pada tiap orang dapat berbeda.
Banyaknya anggota kelompok membuat perlakuan terhadap ODHA terkadang tidak sesuai dengan yang dibutuhkannya. Respoden juga ada yang melakukan pekerjaan sambilan dimalam hari sebagai pekerja seks dan mayoritas ODHA di Kota Depok saat ini juga terdapat pada kelompok laki seks laki. Tidak semua orang dapat menerima hal ini. Stigma terhadap beberapa hal tersebut juga masih tinggi. Walaupun ODHA tersebut mendapat dukungan persahabatan dari LSM, akan tetapi dukungan persahabatan lainnya tidak terpenuhi. ODHA juga susah untuk mencari pekerjaan dan rentan kehilangan pekerjaan. Sehingga rasa memiliki atau tergabung dalam suatu kelompok pekerjaan yang dimiliki ODHA rendah dan dapat meningkatkan stres pada ODHA tersebut.

Beberapa keterbatasan penelitian ini antara lain penggunaan kuesioner PSS-HIV. Alat ini belum pernah digunakan di Indonesia sehingga perlu diterjemahkan ke dalam Bahasa Indonesia. Sayangnya, proses penerjemahan ini tidak melalui prosedur standar. Penelitian ini juga tidak menguji variabel lain yang berkaitan dengan dukungan sosial, seperti sumber dukungan dan status pernikahan responden. Faktor lain yang dapat memengaruhi tingkat stres pada ODHA, yang kemungkinan menjadi faktor perancu juga tidak diteliti.

\section{Kesimpulan}

Terdapat hubungan yang signifikan antara dukungan sosial dengan tingkat stres penderita HIV/AIDS. Hanya dukungan materi yang mempunyai hubungan signifikan dengan tingkat stres. Dukungan emosi, materi, informasi, dan persahabatan tidak memiliki hubungan yang signifikan dengan tingkat stres.

Hasil penelitian ini merekomendasikan dukungan sosial bagi ODHA untuk mengurangi tingkat stres. Akan tetapi, penelitian selanjutnya perlu dilakukan untuk menguji faktor lain yang berhubungan dengan dukungan sosial dan tingkat stres pada ODHA dengan jumlah sampel 
yang lebih besar. Meskipun mungkin sulit, tetapi penelitian pada ODHA yang belum mendapatkan pendampingan LSM juga perlu dilakukan (AW, INR).

\section{Referensi}

Abrefa-Gyan, T., Wu, L., \& Lewis, M.W. (2015). Social support and support groups among people with HIV/AIDS in Ghana. Social Work in Health Care, 55 (2), 144-160. doi: 10.1080/00981389.2015.1084969.

Agustanti, D. (2006). Hubungan dukungan sosial dengan kualitas hidup ODHA (Tesis, tidak dipublikasikan). Fakultas Ilmu Keperawatan Universitas Indonesia, Depok.

British Broadcasting Cooperation (BBC). (2015). Data Kemenkes: Ibu rumah tangga tertinggi $H I V$. Diperoleh dari http://www.bbc.com/ indonesia/beritaindonesia/2015/12/151130_i ndonesia_hiv_iburumahtangga.

Berman, A.T., Snyder, S., \& Frandsen, G. (2015). Kozier \& Erb's fundamentals of nursing: Concept, process and practice (10th Ed.). Cambridge: Pearson Publisher UK.

Campbel, C., Mamame, S., Nair, Y., \& Sybia, Z. (2005). Understanding and challenging HIV/AIDS. South Africa: HIVAN. Diperoleh dari http://eprints.lse.ac.uk/12270/

Casale, M., \& Wild, L. (2013). Effects and processes linking social support to caregiver health among HIV/AIDS-affected carerchild dyads: A critical review of the empirical evidence. AIDS and Behavior, 17 (5), pp 1591-1611. https://doi.org/10.10 07/s10461-012-0275-1

Earnshaw, V. A., Lang, S. M., Lippitt, M., Jin, H., \& Chaudoir, S. R. (2015). HIV stigma and physical health symptoms: Do social support, adaptive coping, and/or identity centrality act as resilience resources? AIDS and Behavior, 19 (1), 41-49. http://doi.org/10.10 07/s10461-014-0758-3
Freeman, E., \& Anglewicz, P. (2012). HIV prevalence and sexual behaviour at older ages in rural Malawi. International Journal of STD \& AIDS, 23 (7), 490-496. http://doi. org/10.1258/ijsa.2011.011340

Kaijage, T., \& Wexler, S. (2010). The influence of stress an social support on adherence to health promotion strategies by people living with HIV/AIDS in Dar es Salam, Tanzania. Journal of HIV/AIDS \& Social Service, 9, 220-339.

Kementerian Kesehatan RI. (2014). Infodatin: Situasi dan analisis HIV/AIDS. Diperoleh dari http://www.depkes.go.id/resources/dow nload/pusdatin/infodatin/Infodatin\%20AIDS .pdf.

Khamarko, K., \& Myers, J.J. (2013). The Influence of social support on the lives of HIVinfected individuals in low- and middleincome countries. Geneve: World Health Organization. Diperoleh dari http://apps. who.int/iris/bitstream/10665/93529/1/WHO _HIV_2013.51_eng.pdf

Kose, S., Mandiracioglu, A., Mermut, G., Kaptan, F., \& Ozbel, Y. (2012). The social and health problems of people living with HIV/AIDS in Izmir, Turkey. The Eurasian Journal of Medicine, 44 (1), 32-39. http://doi.org/10.5152/eajm.2012.07

Kusuma, H. (2011). Hubungan Depresi dan Dukungan Keluarga dengan Kualitas Hidup Pasien HIV/AIDS yang Menjalani Perawatan di RSUPN Cipto Mangunkusumo Jakarta (Tesis Magister, tidak dipublikasikan). Fakultas Ilmu Keperawatan Universitas Indonesia, Depok - Jawa Barat.

Lyons, S.J., \& Gillis, J.R. (2010). The role of social support and psychological resources in depression in people living with HIV/AIDS: Examining the mediating role of mastery and self-esteem (Unpublished dissertation, Department of Adult Education and Counselling Psychology). University of Toronto, Canada. Diperoleh dari https://ts pace.library.utoronto.ca/handle/1807/24230. 
Natalya, W. (2006). Mekanisme dan strategi koping orang dengan HIV/AIDS (ODHA) dalam menghadapi stres akibat penyakitnya di Yogyakarta (Tesis, tidak dipublikasikan). Fakultas Ilmu Keperawatan Universitas Indonesia, Depok.

Rachmanissa, K. (2013). Hubungan kelompok dukungan sebaya terhadap kepatuhan terapi antiretroviral (ARV) pada penderita HIV\&AIDS di Jakarta Timur (Skripsi, tidak dipublikasikan). Fakultas Ilmu Keperawatan Universitas Indonesia, Depok.

Sarafino, E., \& Smith, T.W. (2012). Health psychology: Biopsychosocial interactions (7th Ed.). New York: Jhon Wiley \& Sons. INC Pte Ld.

Tang, H. (2001). Impact of social support and stress on health-related quality of life among people living with HIV and Aids (Unpublished Master Thesis). University of Alabama, Birmingham.
Vreeman, R.C., Scanlon, M.L., McHenry, M.S., \& Nyandiko, W.M. (2015). The physical and psychological effects of HIV infection and its treatment on perinatally HIV-infected children. Journal of the International AIDS Society, 18 (7 Suppl 6), 20258. http:// doi.org/10.7448/IAS.18.7.20258

Waluyo, A., Nurachmah, E., \& Rosakawati, R. (2006). Persepsi pasien dengan HIV/AIDS dan keluarganya tentang HIV/AIDS dan stigma masyarakat terhadap pasien HIV/ AIDS. Jurnal Keperawatan Indonesia, 10 (2), 61-69. doi: http://dx.doi.org/10.7454 /jki.v10i2.175

Widyanti, K. (2008). Hubungan antara dukungan sosial dengan kepatuhan menjalani terapi antiretroviral pada orang dengan HIV/ AIDS. (Skripsi, tidak dipublikasikan). Fakultas Ilmu Keperawatan Universitas Indonesia, Depok. 